\title{
Strategi Guru Tahfizh dalam Memotivasi Peserta Didik Menghafal al-Qur'an di SD Semen Padang
}

\author{
Ulfa Rahmi \\ Program Pascasarjana Universitas Muhammadiyah Sumatera Barat \\ ulfarahmi@gmail.com
}

\begin{abstract}
The main problem of this study is about the strategy of tahfiz teachers in motivating students memorizing the Qur'an at Semen Padang Elementary School, first the tahfiz teacher strategy in motivating students from social factors, the Second Tahfiz teacher strategy in motivating students from nonsocial factors. The purpose of the research is to reveal and analyze the strategy of tahfiz teachers in motivating students to memorize the Qur'an at Semen Padang Elementary School. This research is field risearch using descriptive qualitative research methods. The results of the study that the authors found: First; Guru Tahfiz's strategy in motivating students from social factors in memorizing the Qur'an at Semen Padang Elementary School focuses more on motivating by giving advice and encouragement. Second: the strategy of tahfiz teachers in motivating students from non-social factors in memorizing the Qur'an at Semen Padang Elementary School was initially encouraged by the motivation of Ekstrensik because of the school rules, namum during the tahfiz process lived the more days students became aware of the importance of memorizing the Qur'an.
\end{abstract}

Keywords: tahfizh Qur'an; strategy; elementary school

\begin{abstract}
Abstrak
Masalah pokok penelitian ini adalah tentang strategi guru tahfiz dalam memotivasi peserta didik menghafal al-Qur'an di SD Semen Padang, pertama Strategi guru tahfiz dalam memotivasi peserta didik dari faktor sosial, Kedua Strategi guru tahfiz dalam memotivasi peserta didik dari faktor non sosial. Tujuan penelitian yaitu untuk mengungkapkan dan menganalisis strategi guru tahfiz dalam memotivasi peserta didik menghafal al-Qur'an di SD Semen Padang. penelitian ini bersifat lapangan (Field risearch) dengan menggunakan metode penelitian kualitatif deskriptif. Hasil penelitian yang penulis temukan: Pertama; strategi guru tahfiz dalam memotivasi peserta didik dari faktor sosial dalam menghafal al-Qur'an di SD Semen Padang lebih menitikberatkan kepada memotivasi dengan memberikan nasehat dan semangat. Kedua: strategi guru tahfiz dalam memotivasi peserta didik dari faktor non sosial dalam menghafal al-Qur'an di SD Semen Padang pada mulanya memang di dorong oleh motivasi Ekstrensik karena aturan sekolah, namum selama proses tahfiz dijalani makin hari siswa makin sadar pentingnya menghafal al-Qur'an.
\end{abstract}


Kata Kunci: tahfiz qur'an; strategi; sekolah dasar

\section{Pendahuluan}

Pendahuluan harus berisi (secara berurutan) latar belakang umum, AlQur'an adalah keajaiban yang berasal dari Allah serta kekal sebagaimana semakin maju ilmu pengetahuan maka semakin jelas keabsahan mukjizatnya ${ }^{1}$. Allah swt menurunkan al-Qur'an kepada Nabi Muhammad Saw, tujuannya mengajak umat dari kehidupan yang gelap kepada cahaya Allah yang penuh rahmat, serta membimbing manusia kepada jalan yang lurus ${ }^{2}$. Begitu sangat pentingnya eksistensi al-Qur'an bagi ummat manusia, disamping pembimbing moral manusia juga mengilhami segala bidang ilmu ${ }^{3}$. Oleh karenanya al-Qur'an perlu dijaga serta dipelihara. Adapun cara pemeliharaan al-Qur'an adalah hafal, tulis, pelajari, fahami serta diamalkan ${ }^{4}$. Keikutsertaan manusia dalam memelihara al-Qur'an bukan berarti karena Tuhan tidak mampu menjaga al-Qur'an tetapi keikutsertaan manusia menunjukkan iman dan kecintaan seorang hamba kepada tuhannya, kepada Nabinya dan kepada kitab sucinya ${ }^{5}$.

Menghapal al-Qur'an menjadi tradisi turun temurun di kalangan umat Islam. Hashim dan Jemali mengisyaratkan dan mengingatkan agar setiap orang dewasa menunjukkan ayat-ayat al-Qur'an kepada generasi penerus. Keduanya juga menerangkankan jika pengkajian al-Qur'an adalah landasan terhadap kurikulum diseluruh sekolah Negara Islam ${ }^{6}$. Karena al-Qur'an dengan memahami al-Quran ialah bagian diantara cara menyebarkan dan mengajarkan agama yang bisa memperkuatkan akidah serta keimanan.

Ulama-ulama terdahulu kebanyakan merupakan hafizh al-Qur'an di antaranya Imam Syafi'i hafizh al-Qur'an saat umur 9 tahun sudah hafizh al-Qur'an ketiga puluh Juznya diluar kepala ${ }^{7}{ }^{8}$. Demikian pula dengan Muhammad Abduh

${ }^{1}$ Meraj Ahmad Meraj, "Literary Miracle of the Quran,” International Journal of Humanities \& Social Science Studies (IJHSSS) III, no. III (2016): 318-28.

2 M. Quraish Shihab, Tafsir Al-Mishbah Pesan, Kesan Dan Keserasian Al-Qur'an (Bandung: Lentera Hati, 2008).

3 Abd Basir et al., "The Parenting of Parents toward Their Children Education According to Al-Quran Perspective," International Journal of Advanced Science and Technology 29, no. 11 (2020): 2749-53.

4 Maryam Sarkhanloo, "Methods of Nurturing Children's Thinking Based On the Teachings of the Qur'an," The International Journal of Indian Psychology 6, no. 2 (2018): 177-89, https://doi.org/10.25215/0602.078.

5 Aderi Che Noh and Miftachul Huda, "Understanding The Quran Resources as Main Principle for Family Institution in Islamic Education,” Journal of Critical Reviews 7, no. 2 (2020): 68892, https://doi.org/http://dx.doi.org/10.31838/jcr.07.02.126.

6 Ibrahim Hashim and Misnan Jemali, "Key Aspects of Current Educational Reforms in

Islamic Educational Schools," GJAT 7, no. 1 (2017): 49-57, https://doi.org/10.7187/GJAT12620170701.

7 Mahyudin Ritonga, "Bargaining Kata Di Dalam Al Qur'an : Kontroversi Ahli Terhadap Bahasa Al Qur'an,” Akademika 21, no. 2 (2016): 229-54, http://ejournal.metrouniv.ac.id/index.php/akademika/article/view/466. 
pengarang tafsir Al-manar yang hafizh al-Qur'an seluruhnya saat umur 12 tahun dalam masa 2 tahun ${ }^{9}$ dan masih banyak hafizh qur'an yang terkenal maupun yang tidak terkenal. Tahfizh al-Qur'an adalah kegiatan yang sulit, banyak hal yang merintanginya ${ }^{10}$. Diantaranya kemauan yang kurang, bakat dan minat yang tidak ada, hati yang kurang kuat, hafalan yang sering lupa, dan redaksi ayat yang mirip menyebabkan para hafizh al-Qur'an menjadi ragu ${ }^{11}$. Karena banyaknya yang hafizh al-Qur'an maka dapat menjadikan salah satu usaha dalam memelihara keaslian agar redaksinya tidak mampu ditukar atau dirubah-ubah. Allah swt berfirman:

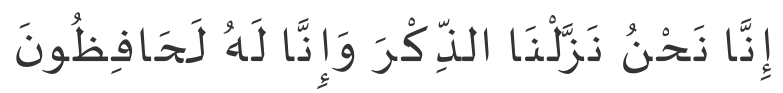

Artinya: "Sesungguhnya Kami-lah yang menurunkan al-Qur'an, dan Sesungguhnya Kami benar-benar memeliharanya" (QS. Al-Hijr ayat 9)

Proses penghafalan al-Qur'an pada peserta didik setingkat SD, sebenarnya bisa dinilai suatu hal yang sulit, di antara alasannya bahwa pendidikan yang berbasis umum, sehingga perhatian terhadap al-Qur'an masih kurang. Supaya mampu menghafal al-Qur'an secara mudah, tentunya diperlukan adanya strategi. Adanya strategi tersebut di samping memberikan kemudahan untuk tahfizh al-Qur'an bisa juga memberikan motivasi tersendiri dalam tahfzih al-Qur'an, bahkan itu juga akan merubah persepsi masyarakat jika menghafal al-Qur'an mempunyai banyak kendala dan sangat susah dalam prosesnya.

Rasulullah Muhammad SAW khawatir jika lupa apa yang dibacakan oleh malaikat Jibril maka beliau tergesa-gesa menghafal dan mengikuti bacaan yang telah disebutkan malaikat Jibril. Oleh sebab itu Allah SWT menegur Nabi Muhammad SAW agar tidak tergesa-gesa mengikuti bacaan Malaikat Jibril. Secara tidak langsung Allah SWT mengajari bahwa mengingat bacaan al-Qur'an perlu ketenangan disebabkan jaminan hafalan al-Qur'an Allah SWT yang menanggungnya. Sahabat Rasul telah menjadi hafizh al-Qur'an saat zaman Rasul masih hidup, Manna Al Qattan menyatakan para penghafal al-Qur'an zaman Rasulullah sangat banyak jumlahnya.

Progam tahfizh al-Qur'an memiliki peranan benar-benar perlu diperhatikan terhadap usaha memperbaiki pendidikan agama Islam, dari sisi proses belajar dan

${ }^{8}$ Mahyudin Ritonga, "Pandangan Para Ahli Bahasa Tentang Bahasa Serapan Dalam AlQuran," Afkaruna: Jurnal Ilmu-Ilmu Keislaman 11, no. 2 (2015): 160-267, https://doi.org/10.18196/AIIJIS.2015.

9 Muslich Shabir, "Muhammad Abduh's Thought on Muhammadiyah Educational Modernism: Tracing The Influence in Its Early Development," QIJIS: Qudus International Journal of Islamic Studies 6, no. 2 (2018): 127-60.

10 Nurlaili, Mahyudin Ritonga, and Mursal, "Muroja'ah Sebagai Metode Menghafal AlQur'an Studi Pada Rumah Tahfiz Yayasan Ar-Rahmah Nanggalo Padang," Menara Ilmu XIV, no. 02 (2020): 73-82.

${ }^{11}$ Reni Fauziah, Mahyudin Ritonga, and Fitri Alrasi, "Korelasi Tsiqah Tahfidz Al-Qur'an Dengan Maharah Al-Lughah Al-'Arabiyyah Mustawa Tsalits Ma'had Az-Zubair Bin Al-Awwam," EL-TSAQAFAH Jurnal Jurusan PBA 19, no. 1 (2020): 25-36, https: journal.uinmataram.ac.id/index.php/eltsaqafah\%0AKORELASI. 
mengajar terhadap pendidikan formal ataupun non formal contoh di TPQ (Taman Pendidikan Al-Qur'an) hingga pesantren. Tahfizh al-Qur'an bisa berfungsi secara langsung untuk upaya penciptaan akhlaq al-karimah mulai usia anak-anak, progam tahfizh al-Qur'an bisa memajukan nilai dalam kepandaian membaca dan menulis alQur'an terhadap anak dan mengembangkan ilmu keislaman anak ${ }^{12}$.

Rancangan tahfizh al-Qur'an memberi kemudahan terhadap para guru untuk mempelajari pengetahuan keislaman yang diajarkan terhadap peserta didik di sebuah organisasi pendidikan formal dan non formal ${ }^{13}$. Guru wajib menjelaskan ayat-ayat al-Qur'an sangat kesulitan dalam memberikan kepahaman dan menjelaskan isi makna al-Qur'an, melalui kebiasaan mengkaji isi al-Qur'an lewat progam tahfizh al-Qur'an, dengan demikian maka dapat mempermudah bagi pendidik dalam menjelaskan materi tentang isi makna al-Qur'an menjadi sumber dalam membahas segala persoalan agama Islam berpondasikan al-Qur'an. Kalau diperhatikan mulai sisi perlunya mengingat ayat-ayat al-Qur'an, sesuatu yang harus dilaksanakan bagi setiap Muslim, apalagi pada masa kanak-kanak ${ }^{14}$, sangat berharga lagi jika seorang yang beriman hafizh al-Qur'an kemudian mengamalkannya serta berdakwah dalam mensyiarkan agama Islam. Untuk mengetahui seberapa perlunya hafizh al-Qur'an maka dapat menjadi renungan pahala bagi apabila membacanya.

Sejak awal Islam, pengkajian tahfizh al-Qur'an selalu berkembang, tapi belakangan ini pembelajaran tahfizh al-Qur'an sudah terdapat pada MadrasahMadrasah, bahkan sekolah yang berbasis pendidikan umum. Disamping itu kegiatan Tahfizh al-Qur'an makin bersemangat karena didukung oleh perguruan tinggi yang memberikan support kepada calon mahapeserta didik yang hafal al-Qur'an 2 atau 5 juz dan 30 Juz masuk tanpa test dan gratis kuliah pada perguruan tinggi tersebut seperti Universitas Indonesia, Universitas Padjajaran, Universitas Gajah Mada, Universitas Diponegoro, Universitas Eka Sakti, Institut Teknologi Bandung. Demikain juga Universitas Andalas yang meluluskan calon mahasiswa tanpa test terhadap yang sudah hafizh al-Qur'an 5 juz ${ }^{15}$.

Pemerintah Pusat, Propinsi serta pemerintah kota Padang telah membuat payung hukum pelaksanaan program tahfizh al-Qur'an di antaranya: Undang-

${ }^{12}$ Sri Slamet, "The Effect of Memorizing Quran on the Children Cognitive Intelligence," Humanities \& Social Sciences Reviewers 7, no. 3 (2019): 571-75, https://doi.org/10.18510/hssr.2019.7384 THE.

${ }^{13}$ Rosniati Hakim et al., "Implementation of Contextual Teaching and Learning in Islamic Education at Madrasah Diniyah," Journal of Advanced Research in Dynamical \& Control Systems 12, no. 02 (2020): 3326-32, https://doi.org/10.5373/JARDCS/V12I2/S20201455.

${ }^{14}$ Rosniati Hakim, Mahyudin Ritonga, and Weti Susanti, "Institute Quality Improvement Through Management Training of Accreditation Preparation in TK Aisyiyah Bustanul Athfal Padang," in Advances in Social Science, Education and Humanities Research, Volume 449 Proceedings of the International Conference of Early Childhood Education (ICECE 2019), vol. 44 (ATLANTIS PRESS Advances in Social Science, Education and Humanities Research (ASSEHR), 2020), 55-65, https://doi.org/https://doi.org/10.2991/assehr.k.200715.012.

${ }_{15}$ Annisa Nurul Mardhiyah and Ayub Ilfandy Imran, "Motivasi Menghafal Al-Qur'an Pada Anak Melalui Komunikasi Interpersonal," Nyimak Journal of Communication 3, no. 2 (2019): 97-105. 
Undang Nomor 20 Tahun 2003 tentang Sistem Pendidikan Nasional dan juga pada pasal 1. PERDA Kota Padang No. 06 Tahun. 2003 tentang kewajiban bagi peserta didik SD/MI pandai BTQ/A dan Peraturan Gubernur No. 70 Tahun 2010 tentang Pendidikan Al-Quran ${ }^{16}$.

Proses penghafalan al-Qur'an setingkat kanak-kanak, sebenarnya bisa dinilai suatu hal yang sulit, di antara alasannya bahwa pendidikan yang berbasis umum, sehingga perhatian terhadap al-Qur'an masih kurang. Supaya mampu menghafal alQur'an secara mudah, tentunya diperlukan adanya strategi. Adanya strategi tersebut di samping memberikan kemudahan untuk tahfizh al-Qur'an juga dapat memberikan motivasi tersendiri dalam tahfzih al-Qur'an, bahkan itu juga akan merubah persepsi masyarakat selama ini bahwa mengingat ayat-ayat al-Qur'an memiliki kesusahan dalam prosesnya.

Strategi pembelajaran sangat dibutuhkan dalam menyampaikan ilmu pengetahuan, apalagi saat menghafal al-Qur'an mesti mempunyai strategi serta metode yang cocok. Contoh bersikap lembut serta sabar dalam melakukan strategi mengajar dan tidak boleh menakut nakuti dan menyulitkan peserta didik, tetapi memberikan kegembiraan dan kenyamanan, agar tujuan yang diinginkan dapat tercapai, dan peserta didik mempunyai semangat dan keinginan sangar keras untuk belajar dan mengembangkan kemampuan yang dimilikinya.

Strategi pembelajaran sangat dibutuhkan dalam menyampaikan ilmu pengetahuan, apalagi saat tahfizh al-Qur'an mesti mempunyai strategi serta metode yang cocok. Contoh bersikap lembut serta sabar dalam melakukan strategi mengajar dan tidak boleh menakut nakuti dan menyulitkan peserta didik, tetapi memberikan kegembiraan dan kenyamanan, agar tujuan yang diinginkan dapat tercapai, dan peserta didik mempunyai semangat dan keinginan sangar keras untuk belajar dan mengembangkan kemampuan yang dimilikinya.

SD Semen Padang adalah sekolah yang terdapat di kota Padang. Sekolah ini termasuk sekolah unggul dari aspek kualitas pendidikannya yang dibuktikan dengan prestasi dan nilai-nilai yang diperoleh oleh para peserta didiknya. SD Semen Padang mengembangkan program pembelajaran tahfizh al-Qur'an sebagai program terbaik. Menurut informasi kepala sekolah SD Semen Padang, bahwa meskipun ini sekolah berbasis pendidikan umum namun tetap memprioritaskan tahfizh al-Qur'an di sekolah, SD Semen Padang lebih memfokuskan program tahfizh al-Qur'an dengan menanamkan pentingnya tahfizh al-Qur'an peserta didik.

Ini dapat terlihat dari hasil yang diperoleh peserta didik dalam pelajaran Agama Islam maupun pelajaran umum yang sangat memuaskan. Juga memuat hasil-hasil karya yang dihasilkan oleh peserta didik yang belajar di SD Semen Padang menggambarkan tingginya tingkat motivasi belajar mereka, dan prestasiprestasi yang mereka raih. Baik dalam pelajaran umum, khususnya di bidang tahfizh al-Qur'an telah mendapat posisi yang penting dan dipertimbangkan. Hal ini

${ }^{16}$ Rosniati Hakim, "Pembentukan Karakter Peserta Didik Melalui Pendidikan Berbasis AlQur'an,” Jurnal Pendidikan Karakter IV, no. 2 (2014): 123-36. 
terbukti setiap peserta didik mampu menghafal minimal 1 juz dan maksimal 3 Juz ketika mereka menyelesaikan pendidikan di SD Semen Padang.

Untuk menjadikan peserta didik hafizh al-Qur'an tentunya ada faktor yang sangat berperan dalam proses tahfizh tersebut. Diantaranya faktor dari keluarga yang sangat mendukung bahkan ingin anak-anaknya menjadi hafizh, sehingga mereka memasukkan anak-anaknya ke pondok tahfizh atau bahkan mendatangkan guru tahfizh ke rumahnya ${ }^{17}$, karena kebanyakan peserta didik yang bersekolah di SD Semen Padang sebagian besar berasal dari orang tuanya yang bekerja sebagai karyawan PT. Semen Padang. Selain itu faktor lingkungan juga dapat mempengaruhi peserta didik, saat anak-anak berada di MDA bergaul dengan teman-temannya yang bersemangat untuk tahfizh al-Qur'an dengan sendirinya mereka juga ikut berlomba untuk menambah hafalan. Dan adapula faktor dari pihak sekolah yang memang mengkhusus program tahfizh al-Qur'an kepada seluruh peserta didik di SD Semen Padang.

Dari uraian di atas, hal yang menarik untuk diteliti di SD Semen Padang yaitu dari faktor Sekolahnya. Sebagai sekolah umum yang sibuk dengan berbagai kegiatan ekstrakurikuler dan intrakurikuler dan tidak di asramakan, dimana SD Semen Padang berhasil mengembangkan pembelajaran tahfizh al-Qur'an tentunya dipengaruhi oleh strategi pembelajaran yang dikembangkan dari sekolah itu, oleh sebab itu penulis melaksanakan penelitian dengan judul: "Strategi Guru Tahfizh alQur'an dalam Memotivasi Peserta didik Menghafal al-Qur'an di SD Semen Padang".

\section{Metodologi Penelitian}

Penelitian ini menggunakan metode penelitian deskriptif kualitatif yaitu memberikan gambaran lebih jelas dan menjelaskan kejadian sebenarnya di tempat penelitian, pelitian yang bukan berbentuk angka atau bilangan. Lebih jelasnya penelitian lapangan (field research) Dalam menyimpulkan penelitian menggunakan analisis SWO'T yaitu dengan membandingkan segala kemungkinan yang terjadi untuk menarik kesimpulan hasil penelitian.

\section{Tabel 1. FAS dan EFAS}

\section{Internal No Strenght / kekuatan Weaknesses / kelemahan}

1 Guru PAI adalah seorang Lokasi Sekolah tidak di pusat Qori Kota

2 Hubungan baik Sekolahnya bukan Sekolah IT ( Islam Terpadu)

3 Manajemen

dalam PPDB tidak dilaksanakan pembelajaran tahfizh al- melalui uji hafalan ayat, yang mengakibatkan tingkat

${ }^{17}$ Fauziah, Ritonga, and Alrasi, "Korelasi Tsiqah Tahfidz Al-Qur’an Dengan Maharah AlLughah Al-'Arabiyyah Mustawa Tsalits Ma’had Az-Zubair Bin Al-Awwam.” 
Qur'an

Tenaga pendidik banyak yang muda.

5 Tingginya motivasi dari guru kepada peserta didik sehingga bisa mengembangkan metode pembelajaran yang efektif.

\section{Eksternal No Opportunities / Peluang}

1 Menjadi salah satu contoh Sekolah umum berbasis Islam

2 Tingginya dukungan dari orang tua, dapat dilihat dengan banyaknya yang mendaftarkan anaknya di SD Semen Padang

3 Peserta didik yang tidak mampu mendapat biaya dari LAZIZ Semen Padang

4 Kerja sama dengan beberapa lembaga pendidikan untuk selalu mengikuti perlombaan

5 Dukungan dari Yayasan melengkapi sarana dan prasana sekolah yang sangat mendukung untuk terdelenggaranya kegiatan tahfizh Al-Qur'an kepandaian peserta didik dalam hal hafalan berbedabeda.

Tidak adanya fasilitas transportasi antar jemput

Minimnya guru tamatan Universitas Agama

\section{Threats / Ancaman}

Banyaknya saingan SDIT yang berada didekat SD Semen Padang

Kondisi keuangan orang tua yang di bawah rata-rata untuk biaya sekolah

Akan muncul Sekolah-sekolah baru yang akan berdiri di sekitar SD Semen Padang

Akan tersaingi dengan SD Negeri yang tidak membayar SPP

Lokasi yang jauh

Tabel 2. Non Sosial dan Sosial

INTERNAL

\section{NO}

Non Sosial

Jurnal WARAQAT • Volume V, No. 2, Juli-Desember 2020 
1. Kerjasama

Hubungan baik antara guru, wali murid serta peserta didik

3. Kemampuan guru tahfizh dalam seni al-Qur'an
Lokasi sekolah

Fasilitas transportasi

Tingkat ekonomi peserta didik berbeda

\section{EKSTERNAL}

NO

1. Kerjasama dengan lembaga pendidikan

2. Persaingan dengan SD Negri dan IT

3. Dukungan wali murid
Non Sosial

Kodisi ekonomi wali murid yang kurang mampu

Bantuan dari LAZIZ Semen Padang

Bantuan dari Yayasan

\section{Hasil dan Pembahasan}

Biasanya hasil belajar peserta didik dapat berpengaruh oleh beberapa faktor, faktor internal dan faktor eksternal. Kedua faktor ini berkesinambungan dalam mempengaruhi proses belajar seseorang yang dapat menentukan kualitas hasil pembelajarannya. Dalam hal ini peneliti hanya membahas faktor eksternal. Faktor eksternal dapat dibagi menjadi dua bagian, yaitu faktor lingkungan sosial dan faktor lingkungan non sosial.

Strategi Guru Tahfizh al-Qur'an dalam memotivasi peserta didik dari faktor sosial dalam menghafal al-Qur'an di SD Semen Padang.

Sesuai dengan hasil penelitian diketahui bahwa setidaknya ada dua factor lingkungan yang mempengaruhi motivasi menghafal al-Qur'an peserta didik di SD Semen Padang, yakni Pertama, Lingkungan sosial. Lingkungan sosial dapat terbagi dalam beberapa bagian, yaitu masyarakat lingkungan alam yaitu semua hal yang mencakup kehidupan selain dari orang. Contohnya rumah, mobil, hewan dan benda lainnya. Kedua, Lingkungan masyarakat yaitu seluruh manusia yang memotivasi seseorang. Tempat tinggal sekitar peserta didik yang kotor, banyak orang dewasa yang tidak mempunyai pekerjaan dan anak-anak yatim piatu yang bisa menjaga mereka juga bisa mempengaruhi pembelajaran.

Lingkungan Sosial keluarga sebagai factor yang mempengaruhi diketahui dari cara orang tua mendididk anaknya sangat berpengaruh besar terhadap belajar 
anaknya. keluarga adalah madrasah pendidikan yang pertama bagi anak-anak. Keluarga yang sehat bermakna besar terhadap pendidikan dalam ukuran kecil, tetapi bersifat penentu terhadap pendidikan dalam ukuran besar yaitu pendidikan bangsa, negara dan dunia. Tempat tinggal yang sering digunakan untuk tenpat acara dan keramaian maka akan dapat mengganggu onsentrasi anak untuk belajar, sebab sangat bising sekali dapat mengganggu belajar anak. Lingkungan sosial sekolah.

Sementara Lingkungan Sekolah, Sekolah merupakan wadah belajar untuk peserta didik dalam mendapatkan ilmu dari guru. Madrasah merupakan wadah belajar untuk peserta didik dan teman-temannya dalam memperoleh ilmu dari guru. Lingkungan sosial sekolah. apabila baik perilaku semua anggota sekolah maka akan membawa dampak yang positif bagi perkembangan karakter dan kemampuan dalam menyerap pelajaran.

SD Semen Padang bukanlah termasuk kategori SD Islam akan tetapi motivasi yang diberikan oleh pihak sekolah yaitu kepala sekolah dan tenaga pendidik luar biasa sekali. Oleh karenanya dengan motivasi yang diberikan dapat memicu semangat peserta didik untuk mau menghafal tanpa dipaksa. Bahkan bukan hanya peserta didik saja yang diberikan motivasi oleh pihak sekolah, akan tetapi orang tuapun dimotivasi sehingga memunculkan semangat orang tua peserta didik untuk ikut memantau perkembangan hafalan serta membantu hafalan peserta didik di rumah.

Minimnya guru lulusan Universitas Agama Islam di SD Semen Padang bukan halangan bagi Sekolah untuk menciptakan prestasi terutama dibidang tahfizh. Karena guru yang mengajar tahfizh di SD Semen Padang adalah Qori tingkat provinsi. Sehingga dengan adanya guru yang pandai seni al-Qur'an akan menjadikan pembelajaran tahfizh semakin menyenangkan bagi peserta didik karena menggunakan irama yang bagus seakan menjadikan pembelajaran tahfizh al-Qur'an tidak menjadi beban bahkan mereka lebih senang membaca al-qur'an dibandingkan bernyanyi.

Biasanya peserta didik baru yang masuk ke SDIT selalu ada tes hafalan. Namun berbeda halnya dengan SD Semen Padang yang menerima peserta didik baru tanpa melihat hafalan peserta didik. Tetapi saat peserta didik telah belajar di SD Semen Padang banyak yang hafalannya berambah. Ini dikarenakan adanya hubungan baik antara tenaga pendidik dan orang tua. Sehingga orang tua selalu diberikan informasi tentang program tahfizh dan perkembangan hafalan peserta didik di Sekolah.

Persaingan dengan SDIT yang berada di sekitar lingkungan SD Semen Padang. Meskipun adanya SDIT namun SD Semen Padang selalu menyetarakan Sekolahnya dengan melakukan kerjasama dengan beberapa lembaga pendidikan yang sering mengadakan perlombaan. Tujuannya adalah untuk menambah prestasi sehingga gaung SD Semen Padang semakin dikenal oleh masyarakat luas sebagai SD umum yang berbasis Islam dan memiliki prestasi dalam bidang tahfizh alQur'an. 
Tingginya tingkat kemauanan orang tua untuk menjadikan anaknya berakhlak serta hafal al-Qur'an menjadikan banyaknya bermunculan sekolahsekolah baru di sekitar lingkungan SD Semen Padang. Hal ini merupakan salah satu ancaman bagi SD Semen Padang. Oleh karena itu SD Semen Padang pun meningkatka kualitas sekolahnya terutama bidang tahfizh dengan mengadakan kerja sama dengan STAIPIQ untuk membantu membimbing hafalan peserta didik SD Semen Padang. Sehinga dengan kerja sama tersebut dapat menambah tenaga pengajar tahfizh al-Qur'an yang dapat memaksimsimalkan hasil yang ingin dicapai.

Peserta didik yang bersekolah di SD Semen Padang semuanya tidak sama. Tidak semua peserta didik yang berasal dari keluarga yang berpendidikan tinggi namun karena adanya dukungan dari wali murid yang mau berusaha agar anaknya bisa bersekolah di SD Semen Padang.

Dalam menghafal al-Qur'an adakalanya peserta didik perlu dimotivasi dengan bergabagai cara apakah melalui peraturan, nilai dan sebagai nya, namun ada juga peserta didik yang tidak perlu dimotivasi kaena bakat dan hobinya mengahafal al-Qur'an. Bagi peserta didik yang mempunyai kemauan yang tinggi dalam menghafal al-Qur'an tidak perlu dimotivasi. Sedangkan yang perlu di motivasi secara ekstrinsik peserta didik yang tidak ada kemauan mengahafal bahkan adakalanya dipaksa sampai peserta didik tersebut merasa senang untuk menghafal.

Motivasi yang diberikan guru tahfizh SD Semen Padang sangat memacu semangat peserta didik SD Semen Padang untuk hafal al-Qur'an karena peserta didik sangat ingin dipasangkan mahkota sebagai wujud bakti seorang anak yang telah dibesarkan oleh orang tuanya bersusah payah. Peserta didik juga saling termotivasi karena banyaknya hafalan peserta didik lain yang dapat dilihat dari buku kontrol monitoring hafalan peserta didik. Selain itu peserta didik juga termotivasi ingin menjadi juara atau yang terbaik saat wisuda tahfizh agar kedua orang tua mereka merasa bangga dan bahagia. Dan motivasi ini juga diberikan oleh guru-guru kepada wali murid sehingga mereka wali murid ingin juga anak-anaknya meraih juara karena itu adalah suatu kebanggaan tersendiri bagi mereka kepada anakanaknya. Karena komunikasi yang terjalin baik antara orang tua dan tenaga pendidik sangat memudahkan bagi guru untuk selalu bertukar pendapat dengan walimurid, oleh sebab itu wali murid berlomba-lomba memacu hafalan anakanaknya di rumah dan sebagian lagi ada juga wali murid yang mengantarkan anakanaknya ke Rumah tahfizh saat pulang sekolah.

Kenyamanan adalah kondisi yang diharapkan dalam belajar. Jika pikiran atau perasaan tidak nyaman maka sulit untuk fokus dalam meghafal al-qur'an. Oleh karena itu tahfizh di SD Semen Padang dilaksanankan pada waktu pagi atau masuk dalam kurikulum wajib. Serta motivasi yang selalu diberikan oleh guru sangat memicu semangat mereka dalam meghafal al-qur'an bahkan juga semangat orang tua wali murid yang ikut juga berlomba-lomba membantu anak-anaknya menambah hafalan di rumah. 
Adapun motivasi yang diberikan yaitu berupa reward yang diadakannya wisuda tahfizh setiap tiga bulan. Dengan kompre massal lalu dilanjutkan pemilihan finalis kompre hafalan, yang diambil pada masing-masing tingkatan dari kelas 1 sampai kelas 6 sesuai dengan beban hafalan yang telah diprogramkan oleh Sekolah.

\section{Strategi Guru Tahfizh al-Qur'an dalam memotivasi peserta didik dari faktor non sosial dalam menghafal al-Qur'an di SD Semen Padang.}

Adapun factor non social yang mempengaruhi motivasi menghapal alQur'an iala dapat dipengaruhi oleh: pertama, Lingkungan alamiah, contoh kondisi cuaca, udara, dan lain sebagainya. Lingkungan alamiah tersebut adalah salah satu faktor-faktor yang mampu mempengaruhi kegiatan belajar. Dan sebaliknya, apabila keadaan lingkungan alam tidak menyenangkan maka akan dapat menghambat proses belajar peserta didik. Kedua, Faktor instrumental, merupakan perangkat belajar yang terbagi dua. Pertama, hardware yaitu perangkat keras yang nampak seperti bangunan sekolah dan fasilitas belajar dan sebagainya. Kedua, software, yaitu perangkat lunak contohnya kurikulum sekolah, peraturan-peraturan sekolah, dan lain sebagainya.

Ketiga, Faktor Materi pelajaran (yang diajarkan kepada peserta didik). Faktor ini harusnya menyesuaikan dengan tingkat perkembangan usia peserta didik, dan selanjutnya metode mengajar yang dipakai oleh guru juga harus menyesuaikan kondisi kematangan peserta didik. Oleh seab itu supaya guru mampu memberikan dampak positif terhadap kegiatan belajar siswa maka guru harus bisa menguasai materi serta berbagai metode mengajar yang sesuai sebagaimana kondisi peserta didik.

Lokasi SD Semen Padang jauh dari pusat kota. Akan tetapi Sekolah menjamin keamanan peserta didik karena lingkungan sekolah yang dipagar tinggi serta adanyan Satpam yang mengawasi dan memantau keluar masuk tamu sekokah. Peserta didik yang belum datang jemputan tidak diperbolehkan keluar dari pekarangan sekolah ataupun keluar dari gerbang penjagaan Satpam. Sehngga ini merupakan salah satu keunggulan bagi Sekolah untuk menarik orang tua agar mau menyekolahkan anak-anaknya ke SD Smen Padang tanpa rasa khawatir jika terlambat menjemput anaknya karena sebagian dari orang tua murid kebanyakan adalah orang-orang sibuk.

Meskipun belum maksimal fasilitas antar jemput di SD Semen Padang, namun karena lokasi sekolah yang asri dan jauh dari keramaian adalah salah satu keunggulan sekolah yang patut diperhitungkan karena sekolah yang tidak bising akan menambah konsentrasi peserta didik dalam belajar.

Peserta didik yang masuk ke SD Semen Padang diterima tanpa dites hafalannya karena di SD Semen Padang program tahfizh masuk ke dalam kurikulum sehingga setiap anak diwajibkan untuk mengahafal al-Qur'an. Jadi bagi anak yang belum hafalpun tidak masalah karena saat sudah mulai bersekolah dan melihat teman-temannya menghafal otomatis dengan sendirinya anak yang belum 
menghafal akan ikut menghafal karena menjadi kebiasaan mendengar bacaan kakak kelasnya.

Banyaknya Sekolah yang berada di pusat kota dan dekat dari tempat orang tua bekerja merupakan salah satu ancaman bagi SD Semen Padang. Nmaun hal ini dapat ditepis karena kelebihan dari sarana dan prasarana yang dimiliki SD Semen Padang salah satunya mushalla dan pekarangan yang luas untuk melakukan bimbingan tahfizh. Selain itu adanya bantuan dari Yayasan yang selalu merenovasi lingkungan sekolah menjadikan sekolah ini nyaman mengadakan tahfizh dimanapun peserta didik suka. Bahkan kadang di taman sekolah melkasanakan bimbingan tahfizh.

Semua peserta didik yang bersekolah di SD Semen Padang tidak semua berasal dari tingkat ekonomi menengah atas. Ada beberapa diantara mereka yang bekerja serabutan bahkan pemulung. Namun karena melihat bagusnya tahfizh di SD Semen Padang merekapun ingin menyekolahkan anak-anak di sana agar bisa menjadi hafizh al-Qur'an. Hal ini sudah ada solusi dari sekolah yaitu adanya bantuan dari LAZIZ Semen Padang yang memberi bea peserta didik bagi peserta didik yang tidak mampu.

Dari wawancara yang penulis lakukan, penulis melihat bahwa siswa hanya menggunakan metode wahdah, yaitu menghafal satu persatu ayat-ayat yang hendak dihafal. Dengan cara membaca setiap ayat sebanyak tujuh kali atau lebih, dengan demikian proses ini bisa membentuk kerangka bayangan dalam pikirannya. Dengan demikian penghafal al-Qur'an mampu mengkondisikan ayat-ayat yang dihafalnya bukan saja dengan bayangannya, akan tetapi benar-benar membentuk gerak reflek pada lisanya.

Menjadi guru Tahfiz tidak mudah, kesabaran sangat dibutuhkan dalam menghadapi berbagai macam sifat peserta didik.terkadang peserta didik menyetor hafalan pulang sekolah otomatis guru tahfiz harus sabar mendengarkan setoran hafalan peserta didik setiap hari pulang sekolah. Kadang kala peserta didik menyetor hafalannya ketika jam istirahat, belum lagi peserta didik yang terbata-bata hafalannya. Kesabaran tidak cukup untuk menghadapi peserta didik, diperlukan keikhlasan karena peserta didik menyetor hafalan setiap hari pulang sekolah sampai jam 18 Wib tentunya menyita waktu guru tahfiz, bahkan peserta didik menyetor hafalannya pada jam istirahat. Namun itulah strategi guru tahfiz dalam memotivasi peserta dalam menghafala al-Qur'an, jika guru tahfiz tahafiz tidak sabar dan tidak ikhlas maka peserta didik akan terkendala dalam mengahafal dan menyetor hafalan karena setiap meyetor hafalan guru tahfiz tidak ada.

\section{Penutup}

Penutup berisi kesimpulan dan saran. Berdasarkan pembahasan yang penulis paparkan, maka dapat disimpulkan Strategi Guru Tahfiz al-Qur'an Dalam Memotivasi Peserta didik Menghafal al-Qur'an di SD Semen Padang sebagai berikut: Pertama, Strategi Guru Tahfizh al-Qur'an dalam memotivasi peserta didik dari faktor sosial menghafal al-Qur'an di SD Semen Padang. Motivasi yang 
diberikan guru tahfizh SD Semen Padang sangat memacu semangat peserta didik SD Semen Padang agar menghafal al-Qur'an karena peserta didik ingin sekali dipasangkan mahkota sebagai wujud bakti seorang anak yang telah dibesarkan oleh orang tuanya bersusah payah. Peserta didik juga saling termotivasi karena banyaknya hafalan peserta didik lain yang dapat dilihat dari buku kontrol monitoring hafalan peserta didik. Selain itu peserta didik juga termotivasi ingin menjadi juara atau yang terbaik saat wisuda tahfizh agar kedua orang tua mereka merasa bangga dan bahagia. Dan motivasi ini juga diberikan oleh guru-guru kepada wali murid sehingga mereka wali murid ingin juga anak-anaknya meraih juara karena itu adalah suatu kebanggaan tersendiri bagi mereka kepada anak-anaknya. Karena hubungan dan kerjasama yang baik diantara orang tua dan guru sangat memudahkan bagi guru untuk selalu bertukar pendapat dengan walimurid, oleh sebab itu wali murid berlomba-lomba memacu hafalan anak-anaknya di rumah dan sebagian lagi ada juga wali murid yang mengantarkan anak-anaknya ke Rumah tahfizh saat pulang sekolah.

Kedua, Strategi Guru Tahfizh al-Qur'an dalam memotivasi peserta didik dari faktor non sosial dalam menghafal al-Qur'an di SD Semen Padang. Adapun motivasi yang diberikan yaitu berupa reward yang diadakannya wisuda tahfizh setiap tiga bulan. Dengan kompre massal lalu dilanjutkan pemilihan finalis kompre hafalan, yang diambil pada masing-masing tingkatan mulai kelas 1 hingga kelas 6 sebagaimana beban hafalan yang telah diprogramkan oleh Sekolah. Selain itu motivasi non sosial yang diberikan oleh guru tahfizh adalah pendekatan dan metode yang digunakan menimbulkan kenyamanan bagi peserta didik dalam mengahfal al-Qur'an serta dengan lingkungan dan sarana yang menyenangkan bagi anak-anak menghafal al-Qur'an.

\section{Referensi}

Basir, Abd, Muhniansyah, Salamah, and Hilmi Mizani. "The Parenting of Parents toward Their Children Education According to Al-Quran Perspective." International Journal of Advanced Science and Technology 29, no. 11 (2020): 2749-53.

Fauziah, Reni, Mahyudin Ritonga, and Fitri Alrasi. "Korelasi Tsiqah Tahfidz AlQur'an Dengan Maharah Al-Lughah Al-'Arabiyyah Mustawa Tsalits Ma'had Az-Zubair Bin Al-Awwam." EL-TS AQAFAH Jurnal Jurusan PBA 19, no. 1 (2020): 25-36.

https: journal.uinmataram.ac.id/index.php/eltsaqafah\%0AKORELASI.

Hakim, Rosniati. "Pembentukan Karakter Peserta Didik Melalui Pendidikan Berbasis Al-Qur'an.” Jurnal Pendidikan Karakter IV, no. 2 (2014): 123-36.

Hakim, Rosniati, Mahyudin Ritonga, Khadijah, and Wetti Susanti. "Implementation of Contextual Teaching and Learning in Islamic Education at Madrasah Diniyah." Journal of Advanced Research in Dynamical \& Control Systems 12, no. 02 (2020): 3326-32. https://doi.org/10.5373/JARDCS/V12I2/S20201455.

Hakim, Rosniati, Mahyudin Ritonga, and Weti Susanti. "Institute Quality Improvement Through Management Training of Accreditation Preparation in 
TK Aisyiyah Bustanul Athfal Padang." In Advances in Social Science, Education and Humanities Research, Volume 449 Proceedings of the International Conference of Early Childhood Education (ICECE 2019), 44:55-65. ATLANTIS PRESS Advances in Social Science, Education and Humanities Research (ASSEHR), 2020. https://doi.org/https://doi.org/10.2991/assehr.k.200715.012.

Hashim, Ibrahim, and Misnan Jemali. "Key Aspects of Current Educational Reforms in Islamic Educational Schools." GJAT 7, no. 1 (2017): 49-57. https://doi.org/10.7187/GJAT12620170701.

Mardhiyah, Annisa Nurul, and Ayub Ilfandy Imran. "Motivasi Menghafal Al-Qur'an Pada Anak Melalui Komunikasi Interpersonal." Nyimak Journal of Communication 3, no. 2 (2019): 97-105.

Meraj, Meraj Ahmad. "Literary Miracle of the Quran." International Journal of Humanities \& Social Science Studies (IJHSSS) III, no. III (2016): 318-28.

Noh, Aderi Che, and Miftachul Huda. "Understanding The Quran Resources as Main Principle for Family Institution in Islamic Education." Journal of Critical Reviews $7, \quad$ no. 2 (2020): 688-92. https://doi.org/http://dx.doi.org/10.31838/jcr.07.02.126.

Nurlaili, Mahyudin Ritonga, and Mursal. "Muroja'ah Sebagai Metode Menghafal AlQur'an Studi Pada Rumah Tahfiz Yayasan Ar-Rahmah Nanggalo Padang." Menara Ilmu XIV, no. 02 (2020): 73-82.

Ritonga, Mahyudin. "Bargaining Kata Di Dalam Al Qur'an: Kontroversi Ahli Terhadap Bahasa Al Qur'an.” Akademika 21, no. 2 (2016): 229-54. http://ejournal.metrouniv.ac.id/index.php/akademika/article/view/466.

_. "Pandangan Para Ahli Bahasa Tentang Bahasa Serapan Dalam Al-Quran." Afkaruna: Jurnal Ilmu-Ilmu Keislaman 11, no. 2 (2015): 160-267. https://doi.org/10.18196/AIIJIS.2015.

Sarkhanloo, Maryam. "Methods of Nurturing Children's Thinking Based On the Teachings of the Qur'an." The International Journal of Indian Psychology 6, no. 2 (2018): 177-89. https://doi.org/10.25215/0602.078.

Shabir, Muslich. "Muhammad Abduh's Thought on Muhammadiyah Educational Modernism: Tracing The Influence in Its Early Development." QIJIS: Qudus International Journal of Islamic Studies 6, no. 2 (2018): 127-60.

Shihab, M. Quraish. Tafsir Al-Mishbah Pesan, Kesan Dan Keserasian Al-Qur'an. Bandung: Lentera Hati, 2008.

Slamet, Sri. "The Effect of Memorizing Quran on the Children Cognitive Intelligence." Humanities \& Social Sciences Reviewers 7, no. 3 (2019): 571-75. https://doi.org/10.18510/hssr.2019.7384 THE. 